\title{
Linear relationships between cherry tomato traits
}

\author{
Bruno Giacomini Sari ${ }^{*}$ Alessandro Dal'Col Lúcio ${ }^{2}$ \\ Cinthya Souza Santana ${ }^{1}$ Sidinei José Lopes ${ }^{2}$
}

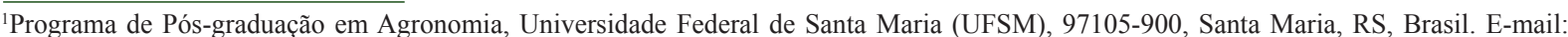
brunosari@hotmail.com. "Corresponding author.

${ }^{2}$ Departamento de Fitotecnia, Centro de Ciências Rurais (CCR), Universidade Federal de Santa Maria (UFSM), Santa Maria, RS, Brasil.
\end{abstract}

\begin{abstract}
The objective of this study was to identify the linear relationship between cherry tomato yield components. Two uniformity trials, without treatments, were conducted on Lilli cherry tomato plants in a plastic greenhouse during the 2014 spring/summer season, with the plants in two stems. Variables observed for each plant were mean fruit length, mean fruit width, mean fruit weight, number of bunches, number of fruits per bunch, total number of fruits, and total fruit weight; a Pearson's correlation matrix was used to estimate the relationship between the variables. Path analysis was then performed considering total fruit weight as the main variable and the remaining variables as explanatory. Due to the severe multicollinearity, the variable 'number of fruits per bunch' was eliminated. Pearson's correlation coefficients were significant between explanatory and main variables. Mean fruit weight has a low cause-and-effect relationship with the total weight of fruits produced. A low cause-and-effect relationship was also observed between number of fruits and number of bunches. Cherry tomato productivity is directly related to the number of fruits per plant.

Key words: Solanum lycopersicum var. cerasiforme, path analysis, correlation.
\end{abstract}

Relações lineares entre caracteres de tomate do tipo cereja

RESUMO: O objetivo deste artigo foi identificar a relação linear entre os componentes da produtividade do tomate cereja. Dois ensaios de uniformidade, sem tratamentos, foram instalados em estufas plásticas nas estações primavera/verão de 2014 com tomate cereja Lilli, com as plantas conduzidas em duas hastes. As variáveis observadas em cada planta foram o comprimento médio de fruto, a sua largura média, o peso médio seu, o número de cachos, o número de frutos por cacho, o número total de frutos e o peso total de frutos, sendo estimada a matriz de correlação de Pearson entre elas. Posteriormente, foi realizada a análise de trilha considerando-se o peso total de frutos como variável principal e as demais como variáveis explicativas. Devido à multicolinearidade severa, optou-se pela eliminação da variável número de frutos por cacho. Os coeficientes de correlação de Pearson, entre as variáveis explicativas e a variável principal, foram significativos. O peso médio de frutos tem baixa relação de causa e efeito com o peso total de frutos produzidos. Também, o número de frutos e o número de cachos apresentaram baixa relação de causa e efeito entre si. A produtividade do tomate cereja está diretamente relacionada com o número de frutos por planta.

Palavras-chave: Solanum lycopersicum var. cerasiforme, análise de trilha, correlação.

\section{INTRODUCTION}

Tomato is an important edible plant cultivated in Brazil. In 2015, 56,880 hectares of tomato plants were cultivated in Brazil resulting in a production of 3,686,816 tons of fruit (IBGE, 2014). Among the various types of tomato, cherry tomato is highlighted in this study due to its use in plate decoration and its use as a starter (GUSMÃO et al., 2006), and also for its higher economic value in the market, as compared to other tomato varieties. The importance of cherry tomato justifies the development of experiments on this plant, and the greater the amount of data collected, the better the chances of researchers to help farmers in an effective way.

When a large number of variables are measured, it is desirable to understand how they are related. The linear relationship between traits is very important in agricultural sciences, mainly for improvement programs, in the indirect selection of genotypes (CRUZ et al., 2006). It can also be an auxiliary tool, demonstrating the level of relationship 
between traits and statistics during planning and experimental conditions, as verified by LÚCIO et al. (2006) on bell peppers and by CARGNELUTTI FILHO et al. (2011) on beans. In addition, knowing the relationship between the production components and productivity may help to decide on the type of handling that should be used.

Pearson's linear correlation is one way to determine the degree of relationship between two variables. However, a simple correlation does not detect the influence of a third variable or group of variables on this relationship, which may lead to incorrect conclusions (CRUZ et al., 2006). Path analysis, proposed by WRIGHT (1921) and WRIGHT (1923), is a technique of multivariate analysis that specifically studies the existing relationship between a set of explanatory variables and a main dependent variable. In this analysis, Pearson's linear correlation is decomposed into direct and indirect effects, allowing the determination of a cause and effect relationship between an explanatory variable and a main variable, independently of the remaining variables (CRUZ et al., 2006).

Linear relationships between production components and productivity are important in improvement programs, as they indicate which trait must be improved or selected in order to obtain the most productive tomato genotypes. Furthermore, comprehending this relationship may help decide which handling approach to adopt. The linear relationship between production components and productivity has been studied in various cultures, such as wet rice (MARCHEZAN et al., 2005), maize (ENTRINGER et al., 2014), salad tomato (RODRIGUES et al., 2010), and wheat (SILVA et al., 2005; GONDIM et al., 2008). However, no studies were found that evaluated the degree of relationship between cherry tomato production components. As such, the aim of this study is to evaluate the linear relationship between productivity components in cherry tomato plants.

\section{MATERIALS AND METHODS}

Two uniformity trials (without treatments) were performed in plastic greenhouses Pampeano type, placed in a north-south orientation, with different dimensions: a $20 \mathrm{~m}$ long and $10 \mathrm{~m}$ wide $\left(200 \mathrm{~m}^{2}\right)$ greenhouse with a height of 3 mon the sides and $4 \mathrm{~m}$ in the central area; and a $25 \mathrm{~m}$ long and $10 \mathrm{~m}$ wide $\left(250 \mathrm{~m}^{2}\right)$ greenhouse with a height of $4 \mathrm{~m}$ on the sides and $5 \mathrm{~m}$ in the central area. Both greenhouses were covered with a low-density polyethylene film with a thickness of 150 micron and anti-UV additive.
In the month before the start of the experiment, the soil $\mathrm{pH}$ was set to 6.5 and the levels of phosphorus to $300 \mathrm{mg} \mathrm{dm}^{-3}$ in both greenhouses. Limestone and phosphorus used to correct the soil were incorporated using a rotary tiller, and ridges measuring approximately $0.20 \mathrm{~m}$ in height and $0.30 \mathrm{~m}$ in width were then created and covered with black opaque film "mulching" strips. Eight ridges were erected in each greenhouse, with a $1 \mathrm{~m}$ distance between each one; drip irrigation was used.

Trails were performed using the Lilli cherry tomato hybrid during the spring/ summer season of 2014. Seedling transplant was performed on the October 26, 2014 when the first sprouting occurred. Seedlings were planted at $0.5 \mathrm{~m}$ distances, in a total of 34 plants per row in the $200 \mathrm{~m}^{2}$ greenhouse and 44 plants in the $250 \mathrm{~m}^{2}$ greenhouse. Fertilization was performed using $150 \mathrm{~kg} \mathrm{ha}^{-1}$ of $\mathrm{N}, 250 \mathrm{~kg} \mathrm{ha}^{-1}$ of $\mathrm{P}$, and $125 \mathrm{~kg}$ $\mathrm{ha}^{-1}$ of $\mathrm{K}$, in both greenhouses. Two topdressing fertilizations were performed with $30 \mathrm{~kg} \mathrm{ha}^{-1}$ of $\mathrm{N}, 15 \mathrm{~kg} \mathrm{ha}^{-1}$ of $\mathrm{P}$, and $30 \mathrm{~kg} \mathrm{ha}^{-1}$ of $\mathrm{K}$ with a 23 day interval between them. Base and top dressing fertilizations were performed based on chemical analysis of the soil and according to the recommendations of the Network of Soil and Plant Tissue Analysis Laboratories of the states of Rio Grande do Sul and Santa Catarina (ROLAS, 2004).

Tomato plants were grown using two stems in both greenhouses, and all lateral growths were eliminated. Every 14 days were applied calcium and boron in order to avoid flower abortion and "black bottom" tomatoes. Fungicides and insecticides were also applied every 14 days to control plagues and diseases.

Each fruit bunch, and each fruit, from all the plants were collected and from them the following variables were measured: a) mean fruit length per plant (MFL, in $\mathrm{cm}$ ), corresponding to the transverse fruit measure; b) mean fruit width per plant (MFWd, in $\mathrm{cm}$ ), corresponding to the longitudinal fruit measure; c) mean fruit weight per plant (MFW, in g); d) number of bunches per plant (NBP); e) number of fruits per bunch (NFB), obtained by dividing the total number of fruits by the total number of bunches; f) number of fruits per plant (NFP); and g) total fruit weight per plant (TFW, in $\mathrm{g}$ ). Measurements were performed with the help of caliper rulers and precision scales $(0.01 \mathrm{~g})$.

Existence of outliers was determined using dispersion graphs and, when they were identified, the outliers were eliminated. From the variables measured in 247 plants from the $200 \mathrm{~m}^{2}$ greenhouse and 347 
plants from the $250 \mathrm{~m}^{2}$ greenhouse, the minimum and maximum values, mean, variance, standard deviation, coefficient of variation, and standard error were estimated. A Pearson's correlation matrix was then constructed and the significance of the correlation coefficients obtained was verified using a t-test $(P$-value $<0.05)$. The means obtained in each plastic greenhouse were compared for each variable using a paired t-test with independent samples $(P$-value $<0.05)$.

A multicollinearity diagnosis was performed from the Pearson's correlation matrix of the variables observed for each trail, and the results were interpreted according to the condition number (CN), as proposed by MONTGOMERY \& PECK (1982). Following that, path analysis was performed considering TFW as the main variable and the remaining variables as explanatory. Genes software was used to perform the analyses (CRUZ, 2006).

\section{RESULTS AND DISCUSSION}

TFW did not differ statistically between the two experiments. The $250 \mathrm{~m}^{2}$ greenhouse produced larger and heavier fruits, but in a lower amount compared to the $200 \mathrm{~m}^{2}$ greenhouse. The NBP in the $250 \mathrm{~m}^{2}$ greenhouse was lower than it was in the $200 \mathrm{~m}^{2}$ greenhouse; however, the NFB did not differ. There was increased variability between the plants $(\mathrm{CV}>20 \%)$ regarding the variables TFW, NBP, $\mathrm{NFP}$, and NFB, and decreased variability regarding the remaining variables (Table 1). Characteristics observed in Lilli hybrids in this experiment are in accordance with the results obtained by AGUIRRE \& CABRERA (2012).

A weak (r values close to zero) or inexistent (non-significant $r$ values) linear relationship was observed between the MFL, MFWd, and MFW, with theNBP, NFP, and NFB. Conversely, the variables NBP, NFP, and NFB showed a strong and positive linear relationship to the TFW ( $r$ values closer to 1), whereas the variables MFL, MFWd, and MFW; although significant, show low $r$ values, indicating a weak relationship with the TFW (Table 2).

As fruits are metabolic drains, it was expected that in plants with a lower number of fruits, the fruit size would increase, due to a higher amount of photoassimilates being available for the development of each individual fruit. As such, a negative linear relationship was expected between the MFW and the NFP, which was not observed. This result can be explained by the fact that the sourcedrain relationship was not significantly affected due to the elevated number of tomatoes per plant.

Table 1 - Number of observations (n), minimum, maximum, mean, variance, standard deviation (SD), and coefficient of variation (CV\%) of the variables mean fruit length per plant (MFL, in $\mathrm{cm}$ ), mean fruit width per plant (MFWd, in $\mathrm{cm}$ ), mean fruit weight per plant (MFW, in g), number of bunches per plant (NBP), number of fruits per bunch (NFB), number of fruits per plant (NFP), and total fruit weight per plant (TFW, in g) observed in two uniformity trails with cherry tomato.

\begin{tabular}{|c|c|c|c|c|c|c|c|}
\hline & TFW & MFL & MFWd & MFW & NBP & NFP & NFB \\
\hline \multicolumn{8}{|c|}{ 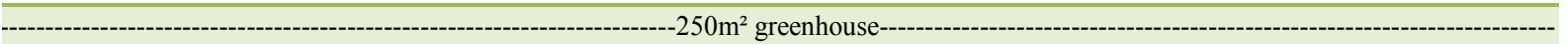 } \\
\hline $\mathrm{n}$ & 347 & 347 & 347 & 347 & 347 & 347 & 347 \\
\hline Minimum & 100.00 & 2.24 & 2.28 & 9.09 & 2.00 & 11.00 & 5.50 \\
\hline Maximum & 3542.00 & 2.99 & 3.31 & 19.18 & 23.00 & 270.00 & 19.50 \\
\hline Mean & $1592.14 \mathrm{a}^{1}$ & $2.61 \mathrm{a}$ & $2.75 \mathrm{a}$ & $13.60 \mathrm{a}$ & $10.46 \mathrm{a}$ & $117.82 \mathrm{a}$ & $11.27 \mathrm{a}$ \\
\hline Variance & 325416.41 & 0.2 & 0.02 & 3.05 & 10.90 & 1788.66 & 5.92 \\
\hline SD & 570.45 & 0.12 & 0.14 & 1.75 & 3.30 & 42.29 & 2.43 \\
\hline $\mathrm{CV} \%$ & 35.83 & 4.66 & 5.23 & 12.84 & 31.56 & 35.90 & 21.58 \\
\hline \multicolumn{8}{|c|}{ } \\
\hline $\mathrm{n}$ & 247 & 247 & 247 & 247 & 247 & 247 & 247 \\
\hline Minimum & 173.00 & 2.20 & 2.27 & 7.23 & 3.00 & 23.00 & 4.60 \\
\hline Maximum & 3016.00 & 2.88 & 3.11 & 16.21 & 22.00 & 225.00 & 20.00 \\
\hline Mean & $1583.52 \mathrm{a}$ & $2.53 \mathrm{~b}$ & $2.70 \mathrm{~b}$ & $12.50 \mathrm{~b}$ & $11.49 \mathrm{~b}$ & $125.36 \mathrm{~b}$ & $10.98 \mathrm{a}$ \\
\hline Variance & 313394.01 & 0.01 & 0.02 & 2.13 & 10.60 & 1701.41 & 6.57 \\
\hline SD & 559.81 & 0.12 & 0.14 & 1.46 & 3.26 & 41.25 & 2.56 \\
\hline $\mathrm{CV} \%$ & 35.35 & 4.69 & 5.12 & 11.67 & 28.34 & 32.91 & 23.34 \\
\hline
\end{tabular}

${ }^{1}$ Mean values followed by the same letter, within each variable and between the two greenhouses, did not differ according to the $\mathrm{t}$-test $(\mathrm{P}$ value $<0.05$ ). 
Table 2 - Pearson's correlation matrix between the variables mean fruit length per plant (MFL, in cm), mean fruit width per plant (MFWd, in $\mathrm{cm}$ ), mean fruit weight per plant (MFW, in $\mathrm{g}$ ), number of bunches per plant (NBP), number of fruits per bunch (NFB), number of fruits per plant (NFP), and total fruit weight per plant (TFW, in g) observed in two uniformity trails with cherry tomato.

\begin{tabular}{|c|c|c|c|c|c|c|c|}
\hline & TFW & MFL & MFWd & MFW & NBP & NFP & NFB \\
\hline TFW & 1 & $0.205^{*}$ & $0.287^{*}$ & $0.239^{*}$ & $0.830^{*}$ & $0.964^{*}$ & $0.565^{*}$ \\
\hline MFL & & 1 & $0.912^{*}$ & $0.874^{*}$ & -0.083 & -0.028 & 0.086 \\
\hline MFWd & & & 1 & $0.888^{*}$ & -0.032 & 0.052 & $0.163^{*}$ \\
\hline MFW & & & & 1 & -0.080 & -0.027 & 0.081 \\
\hline NBP & & & & & 1 & $0.877^{*}$ & 0.092 \\
\hline NFP & & & & & & 1 & $0.560^{*}$ \\
\hline NFB & & & & & & & 1 \\
\hline \multicolumn{8}{|l|}{--1--- } \\
\hline & TFW & MFL & MFWd & MFW & NBP & NFP & NFB \\
\hline TFW & 1 & $0.421^{*}$ & $0.479^{*}$ & $0.599^{*}$ & $0.773^{*}$ & $0.970^{*}$ & $0.572^{*}$ \\
\hline MFL & & 1 & $0.916^{*}$ & $0.768^{*}$ & $0.133^{*}$ & $0.253^{*}$ & $0.242^{*}$ \\
\hline MFWd & & & 1 & $0.796^{*}$ & $0.172^{*}$ & $0.313^{*}$ & $0.290^{*}$ \\
\hline MFW & & & & 1 & $0.282^{*}$ & $0.391^{*}$ & $0.271^{*}$ \\
\hline NBP & & & & & 1 & $0.803^{*}$ & -0.019 \\
\hline NFP & & & & & & 1 & $0.581^{*}$ \\
\hline NFB & & & & & & & 1 \\
\hline
\end{tabular}

${ }^{*}$ Significant according to the t-test (P-value $<0.05$ ), with 345 degrees of freedom in the $250 \mathrm{~m}^{2}$ greenhouse and 245 degrees of freedom in the $200 \mathrm{~m}^{2}$ greenhouse.

Thus, individually, cherry tomato fruits are weak drains (HEUVELINK, 1997; PEIL et al., 2014). The low magnitude linear relationship between the variable TFW and the variables MFL, MFWd, and MFW, and the high magnitude relationship between the variables NBP, NFP, and NFB indicated that, individually, the fruits have little influence on the plant's total production.

It is therefore understood that plants with a higher number of fruits are the most productive. However, this cause-and-effect relationship cannot be truly proved using the Pearson's correlation coefficient, as it does not quantify the influence of other variables on this relationship. Therefore, path analysis was performed in order to determine the cause-and-effect relationship between the production components (explanatory variables) and the production of fruits per plant (dependent variable).

Condition numbers, obtained through the multicollinearity diagnosis from the correlation matrix of the explanatory variables, were higher than 100 in both plastic greenhouses, indicating severe multicollinearity (MONTGOMERY \& PECK, 1982). Among the problems caused by multicollinearity is the variance inflation of the path coefficient estimates, obtaining values that are too high, without biological interpretation. Elimination of explanatory variables is one of the most efficient ways of reducing or eliminating the problem of multicollinearity. As such, the variable NFB was removed from the statistical analyses, which lowered the $\mathrm{CN}$ to 35.80 and 37.02 in the $250 \mathrm{~m}^{2}$ and the $200 \mathrm{~m}^{2}$ greenhouses, respectively (Table 3 ). In this way, the multicollinearity problem was overcome, and path analysis was then performed with the remaining explanatory variables.

The direct, low magnitude, effects of the MFWd, MFL, and MFW on the TFW, in both experiments, confirms that the size of the cherry tomato fruit has little influence on total production. The elevated same directional magnitude values indicated that the productivity of cherry tomato is highly related to the NFP. The NBP has a low direct effect on the TFW, even though it showed a high r-value (Table 3). The indirect effect of the NBP through a positive, high magnitude NFP indicates that the number of bunches is closely related to the number of fruits. This is expected since for the plant to produce more fruit, more floral bunches need to be fertilized.

Therefore, results showed that cherry tomato production is directly related to the number 
Table 3 - Estimates of Pearson's correlation coefficients and the direct and indirect effects of the variables mean fruit length per plant (MFL, in $\mathrm{cm}$ ), mean fruit width per plant (MFWd, in $\mathrm{cm}$ ), mean fruit weight per plant (MFW, in $\mathrm{g}$ ), number of bunches per plant (NBP), number of fruits per bunch (NFB), number of fruits per plant (NFP), and total fruit weight per plant (TFW, in g) observed in two uniformity trails with cherry tomato.

\begin{tabular}{|c|c|c|}
\hline Effect & $250 \mathrm{~m}^{2}$ greenhouse & $200 \mathrm{~m}^{2}$ greenhouse \\
\hline Direct effect of MFLonTFW & -0.004 & 0.011 \\
\hline Indirect effect of MFLthroughMFWd & 0.005 & -0.004 \\
\hline Indirect effect of MFLthrough MFW & 0.232 & 0.195 \\
\hline Indirect effect of MFLthroughNBP & 0.000 & 0.001 \\
\hline Indirect effect of MFLthrough NFP & -0.027 & 0.219 \\
\hline Pearson's correlation & $0.205^{*}$ & $0.421^{*}$ \\
\hline Direct effect of MFWd onTFW & 0.005 & -0.005 \\
\hline Indirect effect of MFWd through MFL & -0.004 & 0.010 \\
\hline Indirect effect of MFWd through MFW & 0.235 & 0.203 \\
\hline Indirect effect of MFWd through NBP & 0.001 & 0.001 \\
\hline Indirect effect of MFWd through NFP & 0.051 & 0.271 \\
\hline Pearson's correlation & $0.287^{*}$ & $0.479^{*}$ \\
\hline Direct effect of MFW on TFW & 0.265 & 0.254 \\
\hline Indirect effect of MFW through MFL & -0.004 & 0.008 \\
\hline Indirect effect of MFW through MFWd & 0.005 & -0.004 \\
\hline Indirect effect of MFW through a NBP & 0.001 & 0.001 \\
\hline Indirect effect of MFW through NFP & -0.027 & 0.339 \\
\hline Pearson's correlation & $0.239^{*}$ & $0.599^{*}$ \\
\hline Direct effect of NBP on TFW & 0.002 & 0.005 \\
\hline Indirect effect of NBP through MFL & 0.001 & 0.001 \\
\hline Indirect effect of NBP through MFWd & 0.001 & -0.001 \\
\hline Indirect effect of NBP through MFW & -0.021 & 0.072 \\
\hline Indirect effect of NBP through NFP & 0.849 & 0.695 \\
\hline Pearson's correlation & $0.830^{*}$ & $0.773^{*}$ \\
\hline Direct effect of NFP on TFW & 0.969 & 0.866 \\
\hline Indirect effect of NFP through MFL & 0.000 & 0.003 \\
\hline Indirect effect of NFP through MFWd & 0.000 & -0.002 \\
\hline Indirect effect of NFP through MFW & -0.007 & 0.100 \\
\hline Indirect effect of NFP through NBP & 0.001 & 0.004 \\
\hline Pearson's correlation & $0.964^{*}$ & $0.970^{*}$ \\
\hline Determination coefficient & 0.999 & 0.998 \\
\hline Residual variable & 0.028 & 0.041 \\
\hline Condition number & 35.805 & 37.023 \\
\hline
\end{tabular}

*Significant according to the t-test (P-value $<0.05)$, with 345 degrees of freedom in the $250 \mathrm{~m}^{2}$ greenhouse and 245 degrees of freedom in the $200 \mathrm{~m}^{2}$ greenhouse.

of fruits produced, and that the individual weight of each fruit has little influence on total production. This result clashes with what is observed regarding salad-type tomato, in which the weight and number of fruits have equal importance in determining the final fruit weight per plant (RODRIGUES et al., 2010). As such, handling actions that aim to increase mean fruit size, or reduce the harvest period, such as apical pruning and fruit thinning, must be performed with caution on cherry tomato plants, as the loss in production caused by the reduction of the number of fruits will not be

Ciência Rural, v.47, n.3, 2017. 
compensated by an increase in MFW as that which occurs in salad-type tomato.

Due to the importance of NFP on cherry tomato production, plant or stem thickening appears to be a promising handling technique in the search for increased productivity. AZEVEDO et al. (2010) and PEIL et al. (2014) verified an increased cherry tomato production in dense cultures, which corroborated the results found in this study. High density planting leads to a reduction in the number of tomatoes per plant due to increased competition between plants. However, this reduction is compensated for by the higher number of plants (and consequently, of fruits) per area, increasing the overall productivity. Therefore, the highest cherry tomato productivity will be reached at the density in which the reduction in number of fruits per plant is no longer compensated by the increase in number of plants per area (PEIL et al., 2014).

Regarding cherry tomato plants, the relationship between number of fruits and total production is extremely important, since the results from this research demonstrated that the reduction in fruit number is not compensated by an increase in fruit size. Consequently, a reduction in the number of cherry tomato fruits leads to a reduction in fruit weight per plant. This is distinct from what occurs with salad-type tomato. Correspondingly, handling practices used to maximize the production of saladtype tomatoes may not be equally effective for cherry tomatoes.

Based on the linear relationships between the variables obtained in this study, it can be verified that tomato productivity is related to the number of fruits a plant produces. As such, the search for an ideal plant density, varying not only the spacing between the plants on each row but also the spacing between rows, can lead to considerable gains in cherry tomato productivity.

\section{CONCLUSION}

Fruit size, mean fruit weight, and the number of bunches per plant showed weak linear relationships with the total fruit weight produced by cherry tomato plants. Number of fruits per plant showed a positive linear relationship with the total fruit weight produced by cherry tomato plants.

\section{ACKNOWLEDGEMENTS}

We would like to thank the Coordenação de Aperfeiçoamento de Pessoal de Nível Superior (CAPES) for providing the first and third author with a fellowship. We acknowledgement the Conselho Nacional de Desenvolvimento Científico e Tecnológico (CNPq) for providing fellowship research for the second and fourth author.

\section{REFERENCES}

AGUIRRE, N.C.; CABRERA, F.A.V. Evaluating the Fruit Production and Quality of Cherry Tomato (Solanum lycopersicum var. cerasiforme). Revista Faculdad Nacional de Agronomia, v.65, n.2, p.6599-6610, 2012. Available from: $<$ http://www.scielo.org.co/scielo.php?script=sci_arttext\&pid $=$ S030428472012000200004>. Accessed: Apr. 09, 2016.

AZEVEDO, V.F. et al. Row spacing and pruning regimes on organically grown cherry tomato. Horticultura Brasileira, v.28, n.4, p.389-394, 2010. Available from: <http://dx.doi.org/10.1590/ S0102-05362010000400002>. Accessed: Apr. 08, 2016. doi: 10.1590/S0102-05362010000400002.

CARGNELUTTI FILHO, A. et al. Number of necessary experiments for the path analysis in common bean. Ciência Rural, v.41, n.4, p.564-572, 2011. Available from: <http://dx.doi. org/10.1590/S0103-84782011005000036>. Accessed: Apr. 07, 2016. doi: 10.1590/S0103-84782011005000036.

CRUZ, C.D. Programa genes: estatística experimental e matrizes. Viçosa: UFV, 2006. 285p.

ENTRINGER, G.C. et al. Correlation and path analysis for yield components of supersweet corn. Revista Ceres, v.61, n.3, p.356361 , 2014. Available from: <http://dx.doi.org/10.1590/S0034737X2014000300009>. Accessed: Apr. 08, 2016. doi: 10.1590/ S0034-737X2014000300009.

GONDIM, T.C.O. et al. Path analysis for yield components and agronomic traits of wheat under defoliation. PesquisaAgropecuária Brasileira, v.43, n.4, p.487-493, 2008. Available from: <http:// dx.doi.org/10.1590/S0100-204X2008000400007>. Accessed: Apr. 08, 2016. doi: 10.1590/S0100-204X2008000400007.

GUSMÃO, M.T.A. et al. Productivity of cherry tomato cultivated in a protected environment and in different substrates. Horticultura Brasileira, v.24, n.4, p.431-436, 2006. Available from: http://dx.doi. org/10.1590/S0102-05362006000400007. Accessed: Apr.09, 2016. doi:10.1590/S0102-05362006000400007.

HEUVELINK, E. Effect of fruit load on dry matter partitioning in tomato. Scientia Horticulturae, v.69, n.1-2, p.51-59, 1997. Available from: <http://dx.doi.org/10.1016/S0304-4238(96)009934>. Accessed: Apr. 03, 2016. doi: 10.1016/S0304-4238(96)00993-4. IBGE (INSTITUTO BRASILEIRO DE GEOGRAFIA E ESTATÍSTICA). Levantamento sistemático da produção agrícola: pesquisa mensal de previsão e acompanhamento das safras agrícolas no ano civil. Rio de Janeiro: IBGE, 2016. 29V. 79p.

LÚCIO, A.D. et al. Temporal variation of the production of peppers affected by plants position and morphologic characteristics of protected crop. Horticultura Brasileira, v.24, n.1, p.3135, 2006. Available from: <http://dx.doi.org/10.1590/S010205362006000100007>. Accessed: Apr. 03, 2016. doi: 10.1590/ S0102-05362006000100007.

MARCHEZAN, E. et al. Path coefficient analysis of rice yield components. Ciência Rural, v.35, n.5, p.1027-1033, 2005. Available 
from: <http://dx.doi.org/10.1590/S0103-84782005000500007>. Accessed: Apr. 05, 2016. doi: 10.1590/S0103-84782005000500007.

MONTGOMERY, D.C.; PECK, E.A. Introduction to linear regression analysis. New York: John Wiley \& Sons, 1982. 504p.

PEIL, R.M.N. et al. Plant density and cherry tomato genotypes in closed substrate growing system. Horticultura Brasileira, v.32, n.2, p.234-240, 2014. Available from: <http://dx.doi.org/10.1590/ S0102-05362014000200021>. Accessed: Apr. 09, 2016. doi: 10.1590/S0102-05362014000200021.

RODRIGUES, G.B. et al. Path analysis of primary and secondary yield components in tomato plants of the Salad group. Pesquisa Agropecuária Brasileira, v.45, n.2, p.155162, 2010. Available from: <http://dx.doi.org/10.1590/S0100204X2010000200006>. Accessed: Apr. 09, 2016. doi: 10.1590/ S0100-204X2010000200006
ROLAS (REDE OFICIAL DE LABORATÓRIOS DE ANÁLISE DE SOLO E DE TECIDO VEGETAL DOS ESTADOS DO RIO GRANDE DO SUL E DE SANTA CATARINA). Recomendações de adubações e de calagem para os estados do Rio Grande do Sul e Santa Catarina. Passo Fundo: SBCSNúcleo Regional Sul, 2004. 224p.

SILVA, S.A. et al. Path analysis for the yield components of seeds in wheat. Bragantia, v.4, n.2, p.191-196, 2005. Accessed: Apr. 01, 2016. Available from: <http://dx.doi.org/10.1590/S000687052005000200004 > doi: 10.1590/S0006-87052005000200004.

WRIGHT, S. Correlation and causation. Journal of Agricultural Research, v.20, n.7, p.57-585, 1921

WRIGHT, S.The theory of path coefficients - a reply to Niles's criticism. Genetics, v.8, n.3, p.239-255, 1923. 